\title{
Can the river speak? Epistemological confrontation in the rise and fall of the land grab in Gambella, Ethiopia
}

Environment and Planning A 2016, Vol. 48(4) 699-717 (C) The Author(s) 2015 Reprints and permissions: sagepub.co.uk/journalsPermissions.nav DOI: $10.1|77 / 03085| 8 X \mid 5610243$ epn.sagepub.com

@SAGE

\section{Bikrum Gill}

University of Victoria, Canada

\begin{abstract}
In this paper, I focus on the role of knowledge production in the rise and fall of the Indian multinational agribusiness firm Karuturi's efforts to become a leading global supplier of food through the initiation of large-scale industrial agricultural production in the Gambella province of Ethiopia. In particular, I interrogate a modernist epistemological framework which privileges the "developmental" knowledge of the Ethiopian state and the "productive" knowledge of Indian capital as central to the urgent task of mastering nature and bringing dormant virgin lands to life, while at the same time it necessarily discounts, through processes of racialization, displaced indigenous peoples and nonhuman life forms as beings incapable of efficient and productive economic activity. My argument in this paper is that while modernist knowledge production and mobilization has been critical to Karuturi's construction of the Gambella land concession as a staging ground for its launch into global prominence in agro-food provisioning, it has also proved fatal to the project, as the epistemological inability to incorporate indigenous knowledge that accounts for "extra-human" agency left the company dramatically unaware of the particular socio-ecological dynamics of the Baro River ecosystem on whose floodplain the land concession was located.
\end{abstract}

\section{Keywords}

Land grab, development, epistemology, primitive accumulation, metabolic rift, Ethiopia, India, south-south, racialization

\section{Introduction}

In 2008, the Indian multinational agri-business firm, Karuturi, made international headlines when it signed an agreement to lease 300,000 ha of land over a period of 50 years in the Gambella province of Ethiopia (Sethi, 2013). Having been offered what it believed to be a huge allotment of prime arable land for next to nothing (\$1 per hectare per year), Karuturi,

\section{Corresponding author:}

Bikrum Gill, Center for Global Studies, University of Victoria, 3800 Finnerty Road, Victoria BC V8P 5C2, Canada.

Email: bikrumsinghgill@gmail.com 
at the time the world's largest rose producer, framed the deal as key to realizing its ambitions of global supremacy in food production and distribution (Dubey, 2012). Dismissing those who critiqued the deal as a paradigmatic example of global land grabbing, the company, along with the Ethiopian government, claimed the land was either unused or not being put to proper use by the indigenous peoples of the province (Dubey, 2012; Rowden, 2011). Noting the incredibly rich organic content of Gambella's soils, along with the abundance of water resources available in the Baro-Akobo river basin in which the land was located, Karuturi's management expressed confidence that, with the proper application of modern industrial farming technology, the company would be able to extract from the land its full productive potential (Bose and Mehra, 2012). Such expectations were frustrated, however, by the very landscape that had seemed so inviting, as the Baro River repeatedly flooded Karuturi's land concession, leaving the future viability of the investment in serious doubt, despite the company having invested a considerable sum of capital (Davison, 2013b; Sethi, 2013). Rather than serve as the staging ground for its launch into global food supremacy, Gambella's rich soil and abundant water sunk Karuturi, as the losses incurred left the company with insufficient capital to carry out the operations at its flagship rose farm in Kenya (Badrinath, 2014).

This paper seeks to account for the role of epistemology in the spectacular rise and dramatic fall of the Karuturi agricultural project in Gambella. In particular, I consider how the Gambella land deal, informed by the systemic capitalist logic of crisis response propelling the global land grab more broadly (McMichael, 2014), mobilizes world-ecological processes of primitive accumulation and metabolic rift (Moore, 2010) that reinaugurate a "mastery over nature" (Leiss, 1972) epistemology premised on an active/passive ontological distinction of society/nature. Key to this distinction, I will argue, is the central role of racialization in collapsing indigenous peoples into the "inferior" sphere of unthinking "irrational" nature, and the corresponding elevation of a "superior" human rationality, embodied in the state-capital development nexus, uniquely capable of productive and efficient resource mobilization. Such an epistemological framework privileges the "developmental" knowledge of the Ethiopian state and the "productive" knowledge of Indian capital as central to the urgent task of mastering nature and bringing dormant land to life, while at the same time it necessarily discounts indigenous peoples and nonhuman life forms as beings incapable of efficient and productive economic activity. My argument in this paper is that while such knowledge production and mobilization has been critical to Karuturi's construction of the Gambella land concession as a staging ground for its launch into global prominence in agro-food provisioning, it has also proved fatal to the project, as the epistemological inability to incorporate indigenous knowledge that accounts for extra-human agency left the company dramatically unaware of the particular socio-ecological dynamics of the Baro River ecosystem on whose floodplain the land concession was located.

In order to forward this argument, I divide the paper into three sections. In the first section, I articulate a theoretical framework that, drawing on world-ecological theory and the concept of coloniality, clarifies how the global land grab, as a phenomenon of the multiple crises epoch, is both informed by, and itself reinaugurates, an epistemology of human mastery over nature. I will consider in particular here the racialized epistemic dimensions of world-ecological cycles of surplus and exhaustion underpinning corresponding moments of renewal and crisis within world-scale colonial-capitalist accumulation. In the second section, the paper focuses on the epistemic constitution of Gambella as a frontier of unused/underused nature whose mobilization in the service of an "ecological surplus" can simultaneously underpin the postcrisis reignition of global 
capital accumulation, the catch-up ambitions of the Indian and Ethiopian developmental states, and the profit-taking imperatives of Karuturi. From here, I move to a consideration of the inherent contradictions and limitations of the mastery over nature epistemic framework informing the Karuturi agricultural project in Gambella, particularly focusing on how the active/passive ontological premise leaves projects of mastery vulnerable to undermining their own socio-ecological foundations. If such an epistemic framework privileges the rational human, embodied most fully in state and capital, as the exclusive knowledge bearing actor of development and production, then it renders itself incapable of responding to the escape of extra-human agency from projects of mastery, as the case of Karuturi's paralysis in the face of its own aggravation of the Baro River's flood patterns clearly reveals.

\section{The next/last frontier? Situating the global land grab within the racialized epistemic order of the capitalist world ecology}

The "capitalism as world-ecology" framework developed by Jason Moore (2010, 2011) provides an important point of departure for the excavation of the foundational systemic processes underpinning the rapid proliferation of large-scale transnational land deals - dubbed the global land grab by more critical observers - within an epoch of multiple, and converging, crises of food, finance, ecology, and energy (Borras et al., 2011). Moore's framework is premised upon a radical rejection of the Cartesian dualism of society/ nature, and as such forwards a reconceptualization of capitalism as constituting in itself a world ecology, rather than simply acting upon, and impacting, an externalized nature. The accumulation of capital, then, expresses a particular constellation of world-ecological relations which, in so far as they are premised on what Moore terms a dialectic of "productivity and plunder," cycle through stages of ecological surplus and exhaustion (Moore, 2010: 392-394). Ecological surplus involves constructing, through, in significant part, the violence of colonial and imperial relations of power, frontiers of undercapitalized nature - i.e. virgin lands - which can then be mobilized to provision the cheap inputs of food and fuel necessary to initiate and sustain capitalist accumulation. The "original" surplus generation underwriting this "transition to capitalism" has historically corresponded with the broader transition ${ }^{1}$ from agrarian to industrial societies which has both been driven by, and provided further growth for, the endless accumulation of capital. In this sense, and as we will see in the case of India and Ethiopia, the pursuit of ecological surplus has been a central focus of states concerned with the achievement of development.

The very logic of endless accumulation comes, however, to eventually draw down this surplus to a state of ecological exhaustion which raises costs and thereby threatens a key constitutive condition of the accumulation of capital. Moore characterizes the moment of ecological exhaustion as a "developmental crisis" of capital, which signals, through rising input costs, the irreversible decline of a specific historical cycle of accumulation (Moore, 2010: 399-406). The overcoming of developmental crisis has, historically, necessitated the reconstitution of world-ecological relations, through the penetration of new frontiers of undercapitalized nature, capable of regenerating the ecological surplus necessary for underwriting a successive accumulation regime.

The contemporary convergence of multiple crises signals, for Moore, the onset of the ecological exhaustion of the neoliberal accumulation regime. What is distinctive about our current moment is that the neoliberal accumulation crisis might be more suggestive of an epochal, rather than developmental, crisis of capital (Moore, 2010: 394). With the exhaustion of the neoliberal ecological surplus, Moore argues that capital may have 
reached its planetary limits, as the ecological exhaustion of previous cycles of accumulation have made it increasingly difficult to identify remaining frontiers of undercapitalized nature that could sufficiently enable the regeneration of the ecological surplus (Moore, 2010: 402).

It is the contention of this paper that, regardless of the material impossibility, the epistemic and ontological order underlying "endless accumulation" has propelled capital to attempt to overcome the neoliberal ecological exhaustion and construct a new ecological surplus, by deepening and widening its constitutive circumstance of primitive accumulation and metabolic rift. Specifically, this is to emphasize that the "dialectic of productivity and plunder" generating cycles of ecological surplus and exhaustion is itself premised upon an epistemic separation of society from nature, and a corresponding hierarchy of being in which the thinking and knowing human subject is conceived as master over unthinking nonhuman natures (Leiss, 1972: 12-23). Expressive of the co-constitution of epistemology and materiality, "mastery over nature" as capitalist society's privileged way of knowing corresponds with what Schneider and McMichael (2010) have identified as the "epistemic rift" which accompanies capital's foundational material emergence through processes of primitive accumulation and metabolic rift. As primitive accumulation separates direct producers from the means of production, enabling their reconstitution as a dispossessed class of labor subject to the "superior" organizational power of profitoriented capital, sustainable socio-ecological metabolic cycles are ruptured as resources extracted through capitalist agricultural production are transferred to urban industry, where "higher" value is located, and are, thus, no longer recycled back into their original agrarian land base (Moore, 2011: 7-10). Within this emergent socio-ecology of capital/labor and metabolic rift, knowledge production and mobilization are increasingly alienated from the co-constitution of human and nonhuman ecologies expressed in the life activity of labor (Schneider and McMichael, 2010: 477). Knowledge, rather, can only be generated by the rational human subject sufficiently removed, in order to provide the necessary objective observation, from the interaction of labor with nonhuman ecology to which said knowledge is to be applied (Araghi, 2009a: 115). Such an epistemic rift denies agency to nonhuman life forces, which are instead understood as irrational external resources awaiting mobilization by superior human rationality for the sake of the "higher" value of capitalist profit. This externalization of nature, as "irrational" other to rational human agency, renders invisible the role of nonhuman ecologies in both constituting and, eventually, exhausting the ecological surplus underpinning capitalist accumulation and development (Schneider and McMichael, 2010: 476-482).

It is important to foreground, however, that the epistemic and ontological premise of capitalist accumulation and development is not simply that of a generalized humanity expressing separation from, and mastery over, an externalized nonhuman nature. The construction, and penetration, of frontiers of undercapitalized nature, on the part of ecological surplus-seeking societies, whether for the purpose of transitioning toward, or regenerating, industrial capitalist development, has materially necessitated, through what Farshad Araghi (2009b, 2012) has termed "global primitive accumulation," the colonial dispossession and displacement of indigenous peoples inhabiting such "virgin lands." As theorists of coloniality have argued, this materiality of colonial dispossession/displacement involves, fundamentally, a corresponding epistemic othering through which indigenous people are racialized as primitive human bodies whose excessive proximity to "irrational" nature renders them incapable of accessing, and mobilizing, the knowledge necessary for productively transforming nature in the service of human development (Mignolo, 2011: 11-12; Quijano, 2000: 555; Wynter, 2003: 264-265). In so much as it renders invisible the co-constitutive role of indigenous knowledge systems and socio-ecological practices in 
sustaining the richness of so-called virgin lands, such epistemic discounting operates as a necessary premise for the externalization of colonial frontiers as "pristine" spaces of "terra nullius"-lands without people - that have hitherto remained untouched by the productive power of human rationality (Povinelli, 1995: 506-507). Thus, the racialized dehumanization of indigenous people and the subjection of colonized land within the mastery over nature epistemic frames of colonizing capitalist societies mobilizes, on the one hand, the "natural" abundance of these lands in the service of the ecological surplus while, on the other, threatening, through the discounting of indigenous ways of knowing, the socio-ecological conditions of possibility for such abundance.

The argument forwarded here, then, is that the world-ecological surplus underpinning historical regimes of capital accumulation is premised upon an epistemic separation of "active" human rationality from "passive" nonhuman nature, integral to which is the collapse of racialized indigenous bodies into the sphere of "irrational" nature. The ecological exhaustion, which eventually draws down the surplus, reveals the fatal contradiction of capital's epistemic order, as the discounting of indigenous ways of knowing and nonhuman agency undermines the biophysical and socio-ecological foundations of the frontier. Within an epistemology of mastery over nature, such exhaustion does not, however, lead to serious reflection on existing human-nature relations, but rather privileges the colonial pursuit, involving global primitive accumulation and metabolic rift, of further frontiers of undercapitalized natures which, once properly mastered, can regenerate the ecological surplus and, in so doing, set in motion a successive accumulation regime.

This particular epistemic premise of capital accumulation, I would further argue, has been a central propulsive force driving the global land grab, thus constituting it as an attempted ecological surplus generating response to the ecological exhaustion of the neoliberal accumulation regime. With such exhaustion being expressed particularly acutely in stagnating global agricultural yield growth (Moore, 2010: 400), much of the rapid proliferation in large-scale agricultural investments across the Global South has been mobilized by the belief, promoted by the World Bank (Deininger et al., 2011) in its most comprehensive report on such land deals, that there is tremendous profit to be realized through the closing of the yield gap, which represents the difference between current and potential production levels on land identified as either unused or underused (McMichael, 2014: 35). Beyond the individual profits to be gained, the closing of the yield gap, through the application of the necessary capital and scale to "underused" land, is represented as having the potential to satisfy the general systemic demand for affordable food and (bio)fuel supplies, and, in so doing, resolve both capital's accumulation crisis and the developmental crisis of states in the South (Deininger et al., 2011; McMichael, 2014). The yield gap concept, then, expresses the mastery over nature epistemic premise of the global land grab, as it signals frontiers of externalized "unused" natures awaiting mobilization by the superior productive capacities of capitalist rationality.

\section{Searching for ecological surplus in Gambella}

\section{State, capital, and the constitution of the frontier}

Included within the World Bank's identification of yield gap regions (Deininger et al., 2011: 189), the Gambella province of Ethiopia has been a particularly prominent, and controversial, site of the global land grab, due in large measure to the attention it has attracted from international human rights NGOs concerned with questions of rural livelihood security and environmental sustainability (HRW, 2012; OI, 2011). While the 
postcrisis concern with global food production has focused increased attention on fertile lands such as Gambella, the province itself has long existed as a frontier within the Ethiopian state. Forcibly incorporated into the highlander-dominated Ethiopian state, via imperial conquests, in the late 19th century, Gambella has historically come to be known, by successive governmental regimes-imperial, the socialist Derg, and the contemporary Ethiopian People's Democratic Revolutionary Front (EPRDF) — as containing lush and fertile lands that, in so much as they were "unused," could resolve the land constraint in the northern highlands and potentially serve as a breadbasket region for Ethiopia, provisioning the cheap inputs that could underwrite the desired national transition from agrarian to industrial economy (Makki, 2012: 83-84; Markakis, 2011: 6). Reflecting the integral role of racialization as a condition of possibility for frontier making, the ecological centrality of Gambella's "virgin" lands to the modernizing mission of the Ethiopian state is enabled by an ontological distinction between civilizing highlander elites, and the indigenous peoples of Gambella, who the imperial highlanders have historically considered to be primitive and backward (Makki, 2012: 84).

The current regime of the EPRDF, which overthrew the Derg in 1991, has continued with the modernizing thrust of the previous regimes, but did initially shift the focus to achieving a program of what they termed "agricultural development led industrialization" through the empowerment, rather than displacement, of small-holder agriculture which would localize development initiatives through greater political decentralization (Lavers, 2012: 108-109). The EPRDF, having come to power on the basis of widespread peasant mobilization and support, believed that the empowerment of small farmers would facilitate increased production and livelihood security, and thus offer a more sustainable and equitable path to industrialization than those attempted by previous regimes (Makki, 2014: 85). However, the failure ${ }^{2}$ of this program to achieve the desired gains in productivity and income, and thus facilitate industrial transition, compelled the EPRDF to pursue a dual track strategy of protecting small-holder agriculture, particularly in the core highland regions, for reasons of livelihood security, while also opening space, through the identification of "unused" lands primarily found in the peripheral Southern lowlands of the country, for the initiation of large-scale agricultural production that could provision the food surplus necessary for underwriting industrialization (Lavers, 2012: 112; Rahmato, 2013). Large-scale agriculture would facilitate the transition by providing cheap food for an emergent industrial proletariat, and by generating foreign exchange, through the export of surplus food, that could then be used to finance the import of the technology and machinery necessary for industrialization (Makki, 2014: 86).

While the EPRDF began to transition to such a dual-track strategy at the turn of the century, the lack of domestic capital and expertise suitable for large-scale agriculture led the regime to emphasize the importance of attracting foreign capital to undertake such initiatives (Rahmato, 2013: 96). Thus, when the political fallout of the global food crisis of 2008 manifested itself, and impressed upon global development and governance organizations, such as the World Bank and the UN Food and Agricultural Organization, the pressing need to identify and close the remaining yield gaps for the sake of global food security (Makki and Geisler, 2011; McMichael, 2014), and revealed to transnational capital the enormous profits that could be potentially realized through agricultural investment, the Ethiopian state identified, and acted upon, such opportunities to operationalize its strategy for foreign capital led large-scale agricultural production (Kebede, 2011).

Embracing the so-called Rise of the South, the Ethiopian state has sought to promote such a development strategy through the channel of South-South solidarity and cooperation. This geopolitical orientation is premised upon the belief that Ethiopia has 
much to gain by engaging with states and capital from the South who, in contrast to Northern actors, could best apply, owing to the similarity in transition and development challenges across the South, the appropriate practices and technology for enhancing agricultural productivity within Ethiopia (Cheru et al., 2013: 24-33). Within the SouthSouth strategy, India has emerged as a particularly prominent partner in the field of agricultural investment and cooperation, as Ethiopia's desire to attract foreign investment in agriculture has converged with India's growing recognition of the need to secure offshore resources for food and biofuel production (Rowden, 2013: 111).

Having been constituted as one of the principal sites of the construction of the ecological surplus during the American hegemonic cycle of global capitalist accumulation, which involved massive increases in agricultural production through the application of green revolution technologies (mechanized cultivation and harvesting instruments, petroleumbased chemical fertilizers, chemical pesticides, hybrid seeds), the Indian agricultural sector is increasingly confronting the implications of ecological exhaustion, of both global and national scales. In particular, the logic of epistemic and metabolic rift that informed the green revolution, centralizing as it does the extractive dimension of agricultural production, while discounting its biophysical foundations, threatens to exhaust in the coming decades the very soils and waters that were mobilized in the forging of the ecological surplus that has underwritten the developmental trajectory of the postcolonial Indian state (Bhattacharya, 2010; Rowden, 2013). Combined with the increasing land constraint that has been imposed by urbanization and industrialization, and Indian agriculture's particular vulnerability to the growing impacts of climate change, such ecological exhaustion has impressed upon the Indian state the need to globalize agricultural production in order, to borrow from Moore's terminology, reconstitute the ecological surplus necessary for the ongoing development project and agrarian transition within India (Pawar, 2014; Rowden, 2013). The promotion of India-Africa trade and investment, under the rubric of South-South solidarity and cooperation, over the past decade, can be understood as such a transnational development strategy, as is evident in the emphasis placed, in the IndiaAfrica forums of 2008 and 2011, on questions of food security and agricultural development in the forging of win-win relations between India and Africa (Singh, 2013: 73).

Through the India-Africa forums, along with bilateral trade initiatives signed with states such as Ethiopia, the Indian state has helped facilitate an enabling trade and investment framework through which Indian capital seeking to expand into transnational agricultural production could align with African states seeking foreign investment to transform "unused" arable land into highly productive units of agricultural production. While the conducive postcrisis investment context has facilitated the expansion of numerous Indian firms into agricultural production in Ethiopia, with several operating in Gambella province alone, the Bangalore-based Karuturi Global has been identified as a pioneer in Indo-African agricultural investment, both for leading the way, in 2008, as the first major investor in Gambella, and for the large scale ${ }^{3}$ at which it has sought to undertake its project (Bose and Mehra, 2012; Dubey, 2012). Initially a floricultural firm, specializing in export-oriented rose production in India, Karuturi expanded its operations to Ethiopia and Kenya in the early 2000 s in order to take advantage of cheaper land and labor costs, more productive soils, and the lower tariff rates that the primary export market for roses, the European Union, offers to exporters based in African countries (Dubey, 2012). After consolidating itself as the largest rose producer in the world by 2007, Karuturi's ambitions turned to achieving supremacy in global food production, as it looked to capitalize on the convergence of the systemic drive to close the global yield gap, the desire of African states to leverage such an imperative to attract foreign investment that could facilitate the achievement of the agrarian surplus 
necessary for industrialization, and the push by the Indian state to secure a longer run source of cheap food and biofuel sources necessary for the continuation of its development trajectory (Bose and Mehra, 2012; Dubey, 2012).

While it is evident that the principal actors of the Gambella land rush are motivated by varying factors, it is my contention that the project as a whole is fundamentally constituted as the penetration of a new untapped frontier, with the aim of constructing an ecological surplus that can provision the cheap food and biofuels necessary for underwriting a new round of global capitalist accumulation and the development trajectories of the Indian and Ethiopian states. In the process, the principal actor responsible for operationalizing the large-scale agricultural production, Karuturi, envisions that it will be rewarded for its role in such ecological surplus making with sustained and high rates of profit. As the earlier discussion made clear, the historical drive to forge an ecological surplus, whether in order to overcome ecological exhaustion or to initiate agrarian transition and industrialization, calls forth processes of primitive accumulation and metabolic rift that are informed by, and further reaffirm, an epistemology of mastery over nature in which the knowing and acting being, the rational human, acts upon the irrational, passive, and "unthinking" nonbeing of nature in order to maximize efficiency through the extractive transfer of resources from low-value nature to higher value industry. In this particular case, the Ethiopian State's claim that "this land is not used by anybody" and thus "it should be developed" (Rowden, 2011: 14), alongside the World Bank's emphasis on the "yield gap," and Karuturi's assertion that this is "virgin land, which has never been plowed for hundreds of years" (Maritz, 2012), suggests that the indigenous pastoralists and subsistence farmers of Gambella are incapable of generating and deploying the knowledge necessary for most effectively utilizing the "free gift" of nature found in Gambella's rich soils and abundant water resources.

\section{Epistemology and socio-ecological formation in Gambella}

Such an assumption is, however, misinformed by the racialized logic of the mastery over nature epistemic order, as it mistakenly assumes that the rich soils and abundant waters are constitutive of dormant virgin lands whose reproduction is not dependent upon the "primitive" inhabitants. An examination of the socio-ecology of the lands leased by Karuturi, which are located in the Jikaw district of Gambella province, reveals instead that the rich soils and abundant waters coveted by modernizing agents are constituted through a complex diversity of socio-ecological interactions in which the livelihood practices of the Anywaa people play a crucial role. While the Anywaa, depending upon the particular ecological region of Gambella within which they live (forests, grasslands, or riverbanks), practice a diverse array of livelihood strategies, those residing within or adjacent to Karuturi's land concession cultivate land along the banks of the Baro River, where annual floods are determinative in shaping the socio-ecological context. During the rainy season, which generally occurs between May and September, the Baro River rises and eventually inundates the lands in its floodplain. Much of this land is normally covered in dense forests, which perform the crucial function of absorbing much of the floodwaters (Woube, 1999: 247). The effects on the land vary depending upon the speed and volume with which the floodwaters cover the plains. On the outer curve of the river, where the water moves rapidly and in high volume, it sweeps away much of the nutrients of the land, leading to soil erosion. On the inner curve of the river, by contrast, the floodwaters move slowly over the land, allowing for the gentle depositing of nutrient-rich organic matter (Kurimoto, 1996: 45; Woube, 1999: 246). 
As Eisei Kurimoto's ethnographic research has shown, the "Anywaa riverbank cultivation is an adaptation to this ecological condition" (Kurimoto, 1996: 44). Specifically, the Anywaa, utilizing a "folk knowledge of the environment," distinguish between the eroded and fertile soils by identifying "two different weeds as indicators of the two parts," and they cultivate exclusively on the fertile soils using a hoe to prepare the land for planting (Kurimoto, 1996: 44). During the rainy season, when the land is submerged under water for several weeks, Anywaa farmers plant local flood-resistant varieties of maize and sorghum which, over many generations, have "adapted to the wet ecological condition." During the dry season, the postflood refertilized soil retains enough moisture to allow for a second planting, a process known as "flood-retreat cultivation" (Feyissa, 2011: 81; Kurimoto, 1996: 45). The flood's annual renewal of the soil's organic content removes the "problem of exhausting soil fertility," allowing for the field to be "continuously cultivated forever unless the river changes its course" (Kurimoto, 1996: 44). The relatively stable and sufficient production levels have provisioned the subsistence needs of the Anywaa, without, however, producing any significant surplus.

Beyond simply responding to nonhuman ecological forces, the cultivation practices of Anywaa farmers have, in turn, played an important role in reproducing the soil and hydrological properties of the riverbanks on which they live. In an investigation of "sustainable land-water management in the lower Baro-Akobo river basin," Mengistu Woube concluded that "floodwater farming systems have been an indispensable component of this humid tropical zone since the early Anuak [Anywaa] settlement" (Woube, 1999: 242). Specifically, Woube argues that the Anywaa's hoe-based cultivation, protection of surrounding forests, and management of wetlands have ensured the proper balance between flooding and land infiltration capacity to allow for annual refertilization, rather than erosion, of the soil.

These particular practices are informed by what we might consider a nonhuman centered, embedded and relational, epistemology. The Anywaa scholar, Ojut Ojulu (2013), in a recent study on the effects of large-scale land acquisitions on indigenous people in Gambella, has argued that "for the Anywa indigenous people in Gambella land is something more than a productive economic resource" (286) and their concept of territory is "not that of the human being controlling and commanding the way in which the territory and its environment has to be governed and exploited" (289). Rather than celebrating a separation from, and mastery over, nature, for the Anywaa "the human being is only part of the bigger community of the living beings taking care of and benefiting from the territory and its environment." Informed by such an epistemological premise, in which other "living beings" steward, and therefore have a claim over, the territory, Anywaa socio-ecological practices do not accord the "right to destroy the forest, because it does not belong to them alone but also to the rest of the living beings dwelling in these forests" and they further maintain that the "water resources have to be used in a way that does not disrupt the survival of the fish and other living beings in it" (Ojulu, 2013: 288).

The interconstitutive relations between Anywaa socio-ecological practices, epistemology, soil fertility, and water flows, were, however, occluded from the Karuturi project's field of vision, which was restricted by what James Scott (1998) has referred to as the "cyclopean shortsightedness of high-modernist agriculture" (264). The narrow focus of high modernist agriculture on production and profit "casts into relative obscurity all the outcomes lying outside the immediate relationship between farm inputs and yields" such as the long-term effects of agricultural practice on "soil structure, water quality, [and] land tenure relations." Reflective of what Scott has called the "imperialism of high-modernist ideology," which seeks to establish the "mastery of nature" through a process of "radical simplification" of 
socio-ecological landscapes, Karuturi and the Ethiopian state isolated, and privileged, the ecological inputs of soil fertility and abundant water which were particularly valuable for short-term productionist aims, and discounted those factors deemed of less immediate value.

Among those factors discounted were the local knowledge and agricultural practices of the Anywaa. During meetings convened in order to inform local communities of the state's intention to lease land to foreign companies for the purpose of large-scale agricultural production, state officials made it clear that the deals were premised upon the Anywaa's incapacity to productively employ the rich resources of Gambella. In one such meeting, the regional governor informed those present that the "lands you are using are not utilized. We have investors coming who will use more efficiently. Those who resist we will take all possible action" (HRW, 2012: 31). On another occasion, officials made clear that "we will invite investors who will grow cash crops. You do not use the land well. It is lying idle" (HRW, 2012: 54). Within the mastery over nature epistemic order driving the Ethiopian development project, then, Anywaa land use is necessarily understood as expressive of an irrational, and hence dangerous, misuse of bountiful resources of fertile soils and abundant waters.

In order, then, for the land to be put to rational use, it is necessary for the productive potential of the capital relation to be deepened in Gambella through processes of primitive accumulation that separate indigenous producers from critical means of subsistence, releasing in the process both land and labor from the "irrational" grip of noncommodified socio-ecological regimes. For those living on Karuturi's land concession, this has involved the company's enclosure, and subsequent clearance, of thousands of hectares of forest that are vital to their socio-ecological reproduction. The forests, besides protecting against erosion, windstorms, and severe floods, provide local Anywaa communities with key resources for home building, medicine, and supplemental food gathering. ${ }^{4}$ Karuturi's clearance of the forests, in order to make way for large-scale agricultural production, was undertaken without any consultation with, or approval from, the communities on whose territory the forests were located. As a farmer from an affected village pointed out, "the local community was not consulted...we simply see them [Karuturi] cutting down the trees but we don't know who allow them."5

Rather than meaningfully consult with local communities, Karuturi project's necessarily called forth the "civilizing mission" which has been integral to the construction and penetration of the colonial-capitalist frontier. In line with the premise that the Anywaa are mired in "backward" or "primitive" agricultural practice, the promoters of this largescale land deal, including the World Bank, the Ethiopian state, and Karuturi, suggested that such a project of agrarian transformation could enhance the livelihood prospects of local communities by facilitating a transition from the poverty trap of subsistence agriculture into better paying jobs on large-scale farms (HRW, 2012: 100, 114-115). In addition, the agricultural project promised, through practices of corporate social responsibility, to connect hitherto isolated Anywaa villages to modern health, education, transportation, and communication networks.

In rendering the Anywaa people and their lands as passive "irrational" natures awaiting modernization by the superior human rationality embodied in state and capital, both the Ethiopian state and Karuturi reveal an epistemic blindness to the complex diversity of mutually constituting human and extra-human ecological actors in Gambella. Such "cyclopean shortsightedness" then allows for "rich" resources, such as fertile soils and abundant water, to be conceived in isolation from less valuable actors, such as the forests and local knowledge systems. Reconfiguring the socio-ecological order, Karuturi sought instead to bring its land to productive life through the introduction of universal industrial 
farming methods (heavy machinery, chemical pesticides, artificial fertilizers) that they argued had proven their worth in a variety of large-scale farming contexts (Bose and Mehra, 2012; Dubey, 2012). In order to rationally manage such a massive and rapid injection of capital, Karuturi, citing again the lack of local expertise, employed experts in the form of agronomists and farm managers who had experience with industrial farming in India, and those with experience with large-scale agriculture from Uruguay (Bose and Mehra, 2012; Dubey, 2012). Armed with the necessary capital and expertise, Karuturi cleared its lands of tens of thousands of hectares of forests, built the necessary dykes to properly harness and restrain the abundant water resources of the Baro River, and declared its intention of having 45,000 ha under cultivation by 2012 (ICRA, 2012a).

\section{The limits of mastery: The rise of the Baro and the fall of Karuturi}

While projects to control and master nature, such as Karuturi's introduction of large-scale industrial agriculture in Gambella, have had far-reaching social and ecological consequences, it is necessary to clarify at this point that the separation of society from nature is more an ideological obfuscation, generated by the changing socio-ecological configurations that result from primitive accumulation and the metabolic rift, than an actual material fact. The point here is that the productive powers of the capital relation are premised upon an epistemological ability to think society as separate from nature, so that resources can be extracted from land without having to account for the wider ecological consequences of such extraction. The very fact of these consequences, what Moore identifies as ecological exhaustion, is a material reminder of the obfuscation presented by modernist epistemology — society might be able to think itself separate from nature, but it only does so at its own peril, since the material fact of the co-constitution of society and nature persists. Thus, the discounting of particular ecological actors in agricultural production forecloses the possibility of recognizing, and responding to, signals of ecological distress and exhaustion.

Beyond simply the persistence of the co-constitution of society and nature, scholars of political ecology are increasingly noting the agency of extra-human natures in escaping projects of mastery and shaping the formation and collapse of socio-ecological regimes. Timothy Mitchell (2002), in his groundbreaking article, Can the Mosquito Speak?, revealed how massive attempts to master and control nature, such as large-scale irrigation development in mid-20th century Egypt, have been profoundly undone and reshaped by nonhuman natures such as malaria spreading mosquitoes. Mitchell's point is that the success of development projects is not achieved by the application of an exterior human expertise upon passive nonhuman nature, but rather involves the formation and deployment of knowledge through a relational ontology in which human and extra-human nature remake one another (2002: 37). While modernizing development projects have been premised upon the epistemic subjugation of the nonhuman, Mitchell argues that it is nonetheless the case that extra-human nature has "never quite accepted this secondary role," and, as was the case with the mosquito in Egypt, the nonhuman often exceeds "human intention" and profoundly reshapes the trajectories of the projects within which human expertise has sought to act upon passive nature (2002: 37).

Mitchell's emphasis on nonhuman agency has been reaffirmed in recent years by critical political ecology perspectives which foreground the "limitations of mastery," in so much as they uncover how the subordination of nature is not equivalent to control (Schneider and McMichael, 2010: 465), and that a "forgotten nature...which could be said to be taking its revenge... is in fact reminding us of its existence" (Serres, cited in Wittman (2009: 807)). Contesting Cartesian dualism, Moore (2010) highlights the constitutive socio-ecological 
dialectic of capitalism as world ecology, in which extra-human nature, while epistemologically discounted, continues to shape, and be shaped by, the emergence and reproduction of capitalist accumulation. The moment of neoliberal ecological exhaustion has, in particular, been defined by the "creative responses of extra-human natures to the disciplines of capitalism" (406).

We can identify such a creative response as central to the stark failure of Karuturi's efforts at large-scale agriculture in Gambella where, despite having invested upward of 150 million US dollars in heavy machinery, sprays, fertilizers, clearing operations, dyke construction, and so on, the operations were "sunk" as the Baro River repeatedly rose up, breached the flood-control dykes, decimated the company's cultivated area, and paralyzed much of the company's heavy machinery that was not designed to act upon waterlogged land (Davison, 2013b; Sethi, 2013). In early 2011, prior to attempting to cultivate its first harvest, Karuturi was attracting global interest in its shares, which were trading at the time at nearly 40 rupees per share, largely due to its successful rose operations in Kenya and the potential that investors recognized in the low-cost high fertile land that Karuturi had secured in Gambella (ICRA, 2012a). Having cultivated 12,000 ha of corn that year, Karuturi expected to employ the returns on its initial harvest to expand the cultivated area to 45,000 ha by May 2012 (ICRA, 2012a). However, in the fall of 2011, as Karuturi prepared to harvest its initial crop of corn, its entire cultivated area of 12,000 ha was inundated with flash floods as the Baro River overflowed and breached the dikes that Karuturi had constructed (Davison, 2011b). The CEO of the company, Ramakrishna Karuturi, expressed shock at the power and scale of the flooding, claiming that the floods could not have been predicted, particularly since they were stronger than any flood in recent memory (Bose and Mehra, 2012; Davison, 2011b). Karuturi, whose epistemological premise rendered him incapable of accounting for such ecological agency or feedback, expressed the limits of his company's expertise in the face of an "irrational" nature, as he claimed that "this kind of flooding we haven't seen before. . this is a crazy amount of water" (Davison, 2011b).

The financial consequences of the flash floods for Karuturi included an immediate 15 million dollar loss, in the form of expected revenue and damaged machinery, and a rapid $85 \%$ collapse in its share price, reflecting investor concerns over the future viability of the project, despite the low-cost high fertile lands on which it was located (Bose and Mehra, 2012; ICRA, 2012; Sethi, 2013). Karuturi's response was not to consult with indigenous farmers who had deep local knowledge of flood patterns and management, but rather to hire expert flood control and drainage firms from India and Holland to assess how best to control any future flooding that might impact its operations (Dubey, 2012). Based upon such expert advice, the company moved to fortify its system of dykes, with the intention of completely altering the dynamics of the floodplain by preventing the flow of any floodwater near their land allotment (Bose and Mehra, 2012; Sethi, 2013). However, the following year, in August 2012, the fortified dykes only aggravated the overflowing waters, first pushing the water back toward the riverbank and causing serious damage to Anywaa villages and farmland, and then eventually, due to the intensification of the force of the water caused by the dykes themselves, the overflowing waters once again breached the dikes and caused substantial damage to the cultivated areas of Karuturi's farm operations (Sethi, 2013).

The company could only make sense of the flooding through the same epistemic frames with which they had approached the investment, and which had foreclosed the agency of extra-human nature and indigenous people, as they argued that the floods were only further evidence that the land, while fertile and cheap, had hitherto been unused due to the antagonistic nature of the floodplain, and thus there was no question of any sort of land 
grabbing. Responding to the land grab narrative in light of the flooding, Karuturi argued that

we have been trying to convince people who've been making these allegations that these are floodplains where nobody stays, where nobody can reside or graze their cattle because most of the time they are under four or five feet of water. (Davison, 2013b)

At the same time, Karuturi excused its own apparent incompetence in managing the floods by claiming that it had no prior knowledge of the extent of the flooding, due to a supposed lack of data on past flooding and rainfall in Gambella (Sethi, 2013).

In making the floods intelligible in this way, however, Karuturi only further reinforces the epistemic foreclosure of modernist epistemology, as it presents the floods as a natural force that must be subdued by modern human expertise, while at the same time denying the presence of indigenous people as thinking and acting beings who have long coexisted with the abundant waters of the Baro River. Contrary to Karuturi's assertions, there have been studies carried out on flood patterns in the Baro Akobo river basin that covers much of Gambella, including one of particular relevance that involved a 15-year study of what were termed "abnormal" flooding patterns between 1985 and 1999 (Woube, 1999). The author of the study drew a distinction between normal and abnormal flooding in Gambella, and argued that the latter, in the form of severe water overflow that negatively affected the livelihoods of indigenous farmers, could be primarily attributed to the ecological change induced by the Derg regime's attempts to introduce large-scale mechanized agriculture into Gambella. In particular, the study found that the deforestation necessary to make space for large-scale agriculture was a key factor in triggering the abnormal flooding in so much as it reduced the water absorption capacity of the land (Woube, 1999).

While the scientific data are not readily available to confirm any link between Karuturi's massive forest clearance and the reduction of water infiltration capacity, affected Anywaa cultivators argue that the floods were intensified by the agricultural practices of the company (Sethi, 2013). Besides the effects of forest clearance, the role of the dykes was identified as central to aggravating and intensifying the floodwaters of the Baro. The dykes, they argued, had blocked the natural flow of the waters, and consequently affected a reverse flow back to the river. ${ }^{6}$ In the absence of alternative infiltration areas, the floodwaters then gathered in even greater force and overwhelmed the dykes. Thus, far from signifying an "irrational" force of nature, the aggressive floodwaters were co-constitutive forces in an emergent socioecology of large-scale industrial agriculture.

From the perspective of the local Anywaa cultivators, the failure of the Karuturi project could be attributed to the epistemic rift that underpinned its efforts to institute a socioecological regime organized around the imperatives of profit-oriented production. As a resident of a village located in the heart of the Karuturi land concession made clear,

Its because he [Karuturi] never consulted the local people about the seasons of planting, this is why he was victim of flood. There is no problem of Baro River for farming. He doesn't listen to any local people - they listened to the highlander experts, but naturally we know the nature of the land. ${ }^{7}$

This discounting of local knowledge left Karuturi unaware of the mutual constitution of a diversity of human and nonhuman ecological actors. Besides drowning Karuturi's project, the aggravated floods wrought by forest clearance and dyke construction risk undermining the fertile soils that had mobilized the project in the first place, as the increase in velocity and volume of the floodwaters threaten to carry away, rather than gently deposit, the rich organic nutrients responsible for the annual refertilization of the soils. 
Beyond aggravating the flooding of the Baro, the failure to involve Anywaa communities as knowledge producing actors fundamentally exposed the "development," or "civilizing mission" pretence of the Karuturi investment in Gambella. Fieldwork observation and interviews in Anywaa villages along the riverbank directly adjacent to Karuturi's cultivated acreage revealed that, though the project disrupted Anywaa livelihoods, it offered little in the way of secure alternatives pointing to a more prosperous future. ${ }^{8}$ Significant among the disruptions, in addition to the adverse social impacts of the flooding mentioned earlier, were the extra distance, due to Karuturi's forest clearance, that villagers had to travel to hunt, collect firewood, and gather medicinal plants. The loss of food supplies and materials, whether due to flooding or forest clearance, was not, as promoters of the project had promised, made up for by food provisioned by Karuturi's more productive farming methods. Much of the acreage was dedicated to cash flex crops, destined for extra-local national, regional, and global markets, rather than the variants of maize and sorghum preferred for local consumption. Locals had little to show, by way of concrete evidence, that could affirm the promises of enhancing village level infrastructure for the health and education sectors. The limited employment generated was described by locals as offering insufficient compensation, particularly in comparison to the wages offered for similar work to highlander employees. Quite often, in fact, wages were simply not paid to Anywaa employees who had worked on the farm. This was reflective, many believed, of the inferiority ascribed to Anywaa labor, as evident most disturbingly in their characterization by Karuturi's farm managers as "nonpeople" (Oakland Institute, 2015: 10).

Local Anywaa communities, it must be emphasized, have responded with various forms of resistance and opposition to the forms of alienation, exploitation, and exclusion visited upon them by large-scale agricultural schemes. Regarding Karuturi specifically, Anywaa workers collectively filed a lawsuit for unpaid wages in the provincial courts of Gambella, exposing in the process Karuturi's impending financial collapse. ${ }^{9}$ More broadly, Anywaa alienation from large-scale agricultural projects has elsewhere been expressed in armed attacks on investors in the heart of "Anywaaland" (Johnson, 2012), as well as in the central role played in antiland grabbing global shaming campaigns by diasporic Anywaa communities, in collaboration with international NGOs, sharing the stories of those marginalized in Gambella who are unable to speak out directly themselves for fear of state repression (Dubey, 2012; Oakland Institute, 2013, 2015). As part of such efforts toward building international solidarity, Anywaa diasporic organizations have developed links with antiland grabbing peasant organizations in India, gesturing perhaps toward more decolonial South-South relationships (Mittal, 2013).

The Anywaa resistance, in exposing the social consequences of the exclusionary premise of Karuturi's venture, works alongside the Baro's floods to caution states and investors against supporting such projects. As a result, Karuturi has been unable to secure financing from creditors increasingly wary of being associated with such a publicized case of land grabbing which, combined with the losses suffered from the persistent flooding detailed above, has significantly hindered the company's ability to continue with operations in Gambella and beyond (Balasubramanyam, 2013; Davison, 2013a; ICRA, 2012b). Forced, by creditors seeking returns on outstanding debts, to relinquish control of its major rose farm in Kenya in 2014 (Wahome, 2014), Karuturi, though quite inactive in Gambella since 2013, formally closed down operations and declared bankruptcy there in early 2015 (Fekade, 2015). 


\section{Conclusion}

The underlying epistemological order that both informs, and is reinaugurated by, the strategies of primitive accumulation and metabolic rift that have been forwarded in the pursuit of the "new" ecological surplus in the postcrisis context, both enabled and undermined Karuturi's attempt to construct Gambella as a staging ground for its launch into global supremacy in food production. While the cheap, fertile land and abundant water resources mobilized Karuturi's investments, the reduction of diverse "natures" to inputs for profit generation left the company unable to account for how such fertility and water abundance had been produced and maintained, rather than simply lying in a dormant, virgin, state, through the mutual constitution of human and extra-human natures that was enabled by the Anywaa's broader epistemological and ontological orders of coexistence. In this case, the drive to extract cheap inputs without accounting for the biophysical foundations of such extraction led to a particularly dramatic and rapid moment of collapse in the attempt to constitute a postneoliberal socio-ecological regime.

The failure of the Karuturi investment in Gambella highlights two significant implications for wider debates on land grabbing, agrarian change, and development. The first concerns the limitations posed by concepts such as the "yield gap" in determining directives for agricultural investment and development. In assuming a "lack" in local capacity, the yield gap epistemic frame ignores how the space between current and potential production levels is actively produced, rather than passively wasted, in order to sustain a given landbase's socioecological conditions of possibility.

The second, and related, implication draws primarily from my fieldwork in Gambella, where an overwhelming majority of those I spoke with in Anywaa communities expressed an eagerness to engage projects of agrarian change which would foster local agricultural innovation and further diversify their livelihood sources. Rather than express a resistance to any sort of change, they emphasized that what they were opposed to was their exclusion from efforts to enhance productivity or further regional and national development. If their participation was made more central Anywaa cultivators insisted that they could facilitate, based upon their own long-standing knowledge systems rooted in the local landbase, more ecologically sensitive and socially inclusive forms of agricultural development that would be less prone to failure than the Karuturi project. Such an approach to agrarian change would, however, require viewing Gambella, not as a frontier of virgin lands and primitive inhabitants, but rather as a dynamic socio-ecology of mutually constituting, and sustaining, human and extra-human life forces.

\section{Acknowledgements}

I am grateful for all of the feedback and suggestions I received from fellow participants at Cornell University's 2014 Summer Institute on Contested Global Landscapes, where a preliminary draft of this paper was presented. Further thanks are due to the anonymous reviewers for their helpful comments and suggestions. As well, special thanks to Demis Mengiste for assistance with fieldwork, and to Ojulu Owala for help with translation.

\section{Declaration of conflicting interests}

The author(s) declared no potential conflicts of interest with respect to the research, authorship, and/or publication of this article. 


\section{Funding}

The author(s) disclosed receipt of the following financial support for the research, authorship, and/or publication of this article: This research was partially made possible by funding from a visiting research fellowship at the Centre for Global Studies, University of Victoria.

\section{Notes}

1. The role of agrarian surplus in the transition from agrarian to industrial society has been a central concern of the Marxian agrarian question framework (Bernstein, 1996). Moore's work is an important world-ecological corrective to the methodological nationalism and anthropocentrism of the agrarian question.

2. The failure of the program, it should be noted, can be attributed to what Berhanu and Poulton (2014) have identified as a tension between the EPRDF's dual objectives of "broad-based agricultural growth" and "political control and mobilization." The latter, in so much as it maintains a patronage approach to agricultural extension, compromised the empowerment of small farmers viewed as necessary for broad-based agricultural growth.

3. In 2010, the Ethiopian national government renegotiated the lease down, from the initial 300,000 ha, to a more "manageable" size of 100,000 ha over a period of 50 years (Davison, 2011a).

4. Fieldwork Interviews, April 2014. This is further confirmed in a new report released by the Oakland Institute (2015).

5. Fieldwork Interview, 26 April 2014.

6. Fieldwork Interviews, 30 April 2014.

7. Fieldwork Interview, 26 April 2014.

8. Fieldwork Interviews, 26-30 April 2014. A recent report released by the Oakland Institute (2015) presents similar findings.

9. Fieldwork Interview, 27 April 2014.

\section{References}

Araghi F (2009a) Accumulation by displacement: global enclosures, food crisis, and the ecological contradictions of capitalism. Review (Fernand Braudel Center) 32(1): 113-146.

Araghi F (2009b) The invisible hand and the visible foot: Peasants, dispossession and globalization. In: Lodhi HA and Kay C (eds) Peasants and Globalization: Political Economy, Rural Transformation and the Agrarian Question. London and New York: Routledge, pp. 111-147.

Araghi F (2012) Land dispossession and global crisis: Introduction to the special section on land rights in the world-system. Journal of World-Systems Research 18(1): 1-5.

Badrinath R (2014) Karuturi's Valentine's Day set to be on a sour note. Business Standard, 13 February. Available at: http://www.business-standard.com/article/companies/karuturi-s-valentines-day-set-to-be-on-a-sour-note-114021301466_1.html (accessed 24 April 2015).

Balasubramanyam KR (2013) An ambition pricked. Business Today, 14 April. Available at: http:// businesstoday.intoday.in/story/ram-karuturi-mulls-taking-his-rose-to-maize-company-private/1/ 193582.html (accessed 24 April 2015).

Bhattacharya A (2010) Green revolution over, agriyields staring at dead end? Times of India, 26 November. Available at: http://timesofindia.indiatimes.com/home/environment/developmentalissues/Green-revolution-over-agri-yields-staring-at-dead-end/articleshow/6991376.cms (accessed 8 May 2014).

Berhanu K and Poulton C (2014) The political economy of agricultural extension in Ethiopia: Economic growth and political control. Development Policy Review 32(s2): s197-s213.

Bernstein H (1996) Is there an Agrarian question in the 21st century? Canadian Journal of Development Studies 27(4): 449-460.

Borras S Jr, Hall R, Scoones I, et al. (2011) Towards a better understanding of global land grabbing: An editorial introduction. Journal of Peasant Studies 38(2): 209-216. 
Bose N and Mehra S (2012) Karuturi global - Don't crave roses if you can't grasp thorns OR How a small Indian company is working overtime to transform East African agriculture. London: London Business School. Available at: http://medial.intoday.in/businesstoday/images/Karuturi-case-studyfull.pdf (accessed 8 May 2014).

Cheru F, Modi R and Naidu S (2013) Catalysing an agricultural revolution in Africa: What role for foreign direct investment?? In: Cheru F and Modi R (eds) Agricultural Development and Food Security in Africa: The Impact of Chinese, Indian and Brazilian Investments. London: Zed Books, pp. 15-37.

Davison W (2011a) Ethiopian Government slashes Karuturi global land concession. Bloomberg, 4 May. Available at: http://www.bloomberg.com/news/articles/2011-05-04/ethiopian-governmentslashes-karuturi-global-land-concession-by-two-thirds (accessed 22 April 2015).

Davison W (2011b) Flood destroys Ethiopia's first corn crop. Bloomberg, 7 October. Available at: http://www.ethiopianreview.com/index/34462 (accessed 10 May 2014).

Davison W (2013a) Karuturi to borrow from sovereign fund after first Ethiopia crop. Bloomberg, 28 March. Available at: http://www.bloomberg.com/news/articles/2013-03-28/karuturi-to-borrowfrom-sovereign-fund-after-first-ethiopia-crop (accessed 22 April 2015).

Davison W (2013b) Ethiopia's farm investment plan falters on floodplain. Bloomberg, 25 November. Available at: http://www.bloomberg.com/news/2013-11-24/ethiopian-drive-to-lure-farm-investm ent-founders-on-flood-plain.html (accessed 10 May 2014).

Deininger K, Byerlee D, Lindsay J, et al. (2011) Rising Global Interest in Farmland: Can It Yield Sustainable and Equitable Benefits?. Washington, DC: The World Bank.

Dubey R (2012) Indian farmer's African safari. Businessworld, 2 June. Available at: http:// www.businessworld.in/news/economy/indian-farmer\%E2\%80\%99s-african-safari/415993/page-1.html (accessed 24 April 2015).

Fekade B (2015) Karuturi under the spotlight. The Reporter, 17 January. Available at: http:// www.thereporterethiopia.com/index.php/news-headlines/item/3045-karuturi-under-the-spotlight (accessed 27 April 2015).

Feyissa D (2011) Playing Different Games: The Paradox of Anywaa and Nuer Identification Strategies in the Gambella Region, Ethiopia. New York: Berghahn Books.

HRW (2012) 'Waiting Here for Death': Forced Displacement and 'Villagization' in Ethiopia's Gambella Region. USA: Human Rights Watch. Available at: http://www.hrw.org/sites/default/files/reports/ ethiopia0112webwcover_0.pdf (accessed 10 May 2014).

ICRA Equity Research Service (2012a) Karuturi Global Limited. ICRA, 3 January. Available at: http://www.icra.in/files/pdf/2011-Jan-Karuturi.pdf (accessed 11 May 2014).

ICRA Equity Research Service (2012b) Karuturi Global Limited. ICRA, October. Available at: http:// www.icra.in/Files/Reports/Rationale/Karuturi\%20Global\%20_r_08102012\%20.pdf (accessed 24 April 2015).

Johnson N (2012) Enough is enough: Gambella, Ethiopia update. Oakland Institute. 1 October. Available at: http://www.oaklandinstitute.org/enough-enough-gambella-ethiopia-update (accessed 24 April 2015).

Kebede B (2011) Land deals in Ethiopia bring food self-sufficiency, and prosperity. The Guardian, 4 April. Available at: http://www.theguardian.com/global-development/poverty-matters/2011/apr/ 04/ethiopia-land-deals-food-self-sufficiency (accessed 8 May 2014).

Kurimoto E (1996) People of the river: Subsistence economy of the Anywaa (Anuak) of Western Ethiopia. In: Sato S and Kurimoto E (eds) Essays in Northeast African Studies. Osaka: National Museum of Ethnology, pp. 29-57.

Lavers T (2012) 'Land grab' as development strategy? The political economy of agricultural investment in Ethiopia. Journal of Peasant Studies 39(1): 105-132.

Leiss W (1972) Domination of Nature. New York: George Braziller.

McMichael P (2014) Rethinking land grab ontology. Rural Sociology 79(1): 34-55.

Makki F (2012) Power and property: Commercialization, enclosures, and the transformation of agrarian relations in Ethiopia. Journal of Peasant Studies 39(1): 81-104. 
Makki F (2014) Development by dispossession: Terra Nullius and the socio-ecology of new enclosures in Ethiopia. Rural Sociology 79(1): 79-103.

Makki F and Geisler C (2011) Development by dispossession: Land grabbing as new enclosures in contemporary Ethiopia. In: International Conference on Global Land Grabbing, Institute for Development Studies, University of Sussex, 6-8 April 2011.

Maritz J (2012) The not so rosy realities of running a large agricultural project in Africa. How We Made It in Africa, 9 June. Available at: http://www.howwemadeitinafrica.com/the-not-so-rosyrealities-of-running-a-large-agriculture-project-in-africa/17344/ (accessed 8 May 2014).

Markakis J (2011) Ethiopia: The Last Two Frontiers. Woodbridge: James Currey.

Mignolo W (2011) The Darker Side of Western Modernity. Durham and London: Duke University Press.

Mitchell T (2002) Rule of Experts: Egypt, Technopolitics, and Modernity. Berkley: University of California Press.

Mittal J (2013) Report from the Indian-Ethiopian Civil Society Summit on Land Investments New Delhi, February 5-7, 2013. Oakland Institute. Available at: http://www.oaklandinstitute.org/ report-indian-ethiopian-civil-society-summit-land-investments-new-delhi-february-5-7-2013 (accessed 27 April 2015).

Moore J (2010) The end of the road? Agricultural revolutions in the capitalist world-ecology. Journal of Agrarian Change 10(3): 389-413.

Moore J (2011) Transcending the Metabolic rift: A theory of crises in the capitalist world-ecology. Journal of Peasant Studies 38(1): 1-41.

OI (2011) Understanding land investment deals in Africa: Country Report, Ethiopia. Oakland: Oakland Institute. Available at: http://www.oaklandinstitute.org/sites/oaklandinstitute.org/files/ OI_Ethiopa_Land_Investment_report.pdf (accessed 8 May 2014).

OI (2013) Unheard voices: The human rights impact of land investments on indigenous communities in Gambella. Oakland: Oakland Institute. Available at: http://www.oaklandinstitute.org/sites/oak landinstitute.org/files/OI_Report_Unheard_Voices.pdf (accessed 27 April 2015).

OI (2015) We say the land is not yours: Breaking the silence against forced displacement in Ethiopia. Oakland: Oakland Institute. Available at: http://www.oaklandinstitute.org/we-say-land-not-yoursbreaking-silence-against-forced-displacement-ethiopia (accessed 27 April 2015).

Ojulu OM (2013) Large-scale land acquisitions and minorities/indigenous peoples' rights under ethnic federalism in Ethiopia. PhD Thesis, Department of Peace Studies, University of Bradford.

Pawar S (2014) Keynote Address Asia-Africa Agribusiness Forum, New Delhi, 4 February. Available at: http://www.ficci.com/events/21682/ISP/Speech-copy-of-Shri-Sharad-Pawar.pdf (accessed 10 May 2014).

Povinelli E (1995) Do rocks listen? The cultural politics of apprehending Australian aboriginal labour. American Anthropologist 97(3): 505-518.

Quijano A (2000) Coloniality of power, Eurocentrism, and Latin America. Nepantla: Views from South 1(3): 533-580.

Rahmato D (2013) Up for Grabs: The case of large Indian investments in Ethiopian agriculture. In: Cheru F and Modi R (eds) Agricultural Development and Food Security in Africa: The Impact of Chinese, Indian and Brazilian Investments. London: Zed Books, pp. 93-106.

Rowden R (2011) India's role in the New Global Farmland Grab. New Delhi: GRAIN and the Economic Research Foundation. Available at: www.networkideas.org/featart/aug2011/ Rick_Rowden.pdf (accessed 8 May 2014).

Rowden R (2013) Indian agricultural companies, 'land grabbing' in Africa and activists' responses. In: Cheru F and Modi R (eds) Agricultural Development and Food Security in Africa: The Impact of Chinese, Indian and Brazilian Investments. London: Zed Books, pp. 107-124.

Schneider M and McMichael P (2010) Deepening, and repairing, the metabolic rift. Journal of Peasant Studies 37(3): 461-484.

Scott J (1998) Seeing Like a State: How Certain Schemes to Improve the Human Condition have Failed. New Haven and London: Yale University Press. 
Sethi A (2013) When the Levee breaks. The Hindu, 19 May. Available at: http://m.thehindu.com/ opinion/lead/when-the-levee-breaks-karuturis-defence/article4727839.ece/ (accessed 10 May 2014).

Singh G (2013) India and Africa: New trends in sustainable agricultural development. In: Cheru F and Modi R (eds) Agricultural Development and Food Security in Africa: The Impact of Chinese, Indian and Brazilian Investments. London: Zed Books, pp. 59-75.

Wahome M (2014) Flower Farm Karuturi put under receivership. Daily Nation, 11 February. Available at: http://www.nation.co.ke/business/Flower-farm-Karuturi-sinks-with-Sh400-millionin-debt/-/996/2202436/-/29637lz/-/index.html (accessed 27 April 2015).

Wittman H (2009) Reworking the metabolic rift: La Via Campesina, agrarian citizenship, and food sovereignty. Journal of Peasant Studies 36(4): 805-826.

Woube M (1999) Flooding and sustainable land-water management in the lower Baro-Akobo river basin, Ethiopia. Applied Geography 19: 235-251.

Wynter S (2003) Unsettling the coloniality of being/power/truth/freedom: towards the human, after man, its overrepresetnation-An argument. CR: The New Centennial Review 3(3): 257-337. 